\title{
非破壊試験による表面疲労亀裂検出に及ぼす塗膜の影響

\author{
NON-DESTRUCTIVE EXAMINATION METHOD OF CRACK DETECTION \\ IN PAINTED STEEL BRIDGE MEMBERS
}

\author{
深沢 誠*·大畦久雄**・加藤昌彦***.三木干寿**** \\ By Makoto FUKAZA WA, Hisao OHUNE, Masahiko KATOH and Chitosi MIKI
}

\begin{abstract}
This study summarized non-destructive methods and evaluates their reliability and adaptability for the detection of fatigue cracks in painted steel bridge members. On the painting, it was possible to detect small cracks up to $5 \mathrm{~mm}$ length with oxide formation by visual examination. And cracks with length longer than $5 \mathrm{~mm}$ were detected by the eddy current examination with the suitable coil and frequency of the current. However, these were poor in the estimation of crack length. A combination of these examination over the paint and the close examination after removing the paint would be a superior detection method. For the estimation of the crack length, the magnetic particle examination was found exellent, allowing the detection of cracks with length longer than 2 $\mathrm{mm}$ with accuracy of better than $1 \mathrm{~mm}$ provided the paint was removed.

Keywords: non-destructive testing, fatigue crack, fillet welded joint, paint
\end{abstract}

\section{1.はじめに}

鋼橋の部材に疲労亀裂の発生している事例が報告され ている ${ }^{1)-5)}$. 図一1 に模式的に示したようにウェブギャッ プの面外変形に起因する隅肉溶接継手の疲労亀裂が多 い. 亀裂が発見された場合の補修方法としては，ガウジ ングにより亀裂を除去して再溶接を行うことが多いが, さらに, 補強板を高力ボルト接合することもある. しか しながら，このような補修・補強方法は対象箇所が多い ことから, 実施段階では相当経費を要することになり, 何亡か経費を節減すべき適切な対策が必要とされてい る. 最近では亀裂を小さいうちに発見して TIG 再溶融 処理を行い, 亀裂の除去とともに止端部の形状改善を行 う補修対策が採られた事例も報告されている ${ }^{6}$. 一方, このような補修・補強作業の中で, 非破壊検査により亀 裂を検出して, 寸法を推定することが必要となるが,

* 正会員 工博 (株) 横河橋梁製作所 ( 下260 千葉市新港 88)

** 正会員 関西エックス線（株） ( ₹733 広島市西区南観音 4-5-11)

*** 正会員 中国エックス線（株） (テ737 広島県吳市 3 条 2-4-10)

**** 正会員 工博 東京工業大学助教授 土木工学科 ( ₹152 目黒区大岡山 2-12-1)

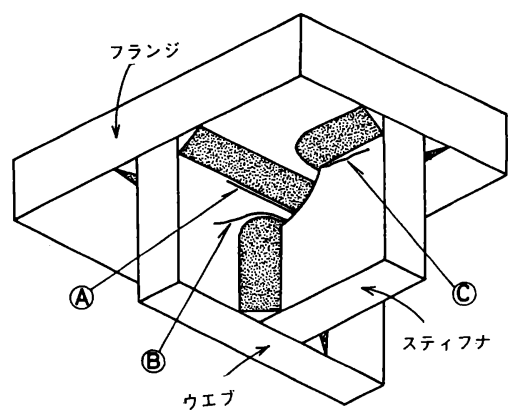

図一1鋼橋部材に発生する疲労绳裂

(1) 種々の非破壊試験の信頼性.

(2) コスト的に有利な補修を行うためにどれくらい小 さな亀裂を検出できるか.

(3)さらに, 今後の破壊力学による寿命予測を行うう えで, ビれくらいの精度で検出できるか.

などの問題点が挙げられている. そこで，著者らは先に 図一1の A，B タイプの亀裂をモデル化した供試体を用 いて, 塗膜のない状態での基本的な非破壊試験の適用性 を検討してきた7). ところで, ほとんどの鋼橋部材の場 合には塗装が施されており，塗膜上からの非破壊試験の 適用性を検討することも重要である．現在，現場での疲 労亀裂の検出に対して最も多く用いられ，信頼できる方 
法は熟練者による目視検査であるといわれている，実際 に, 大部分の亀裂は塗装塗り変え時の錆汁なよ゙の異常に より発見されることが多い。しかし，このような亀裂は すでにかなり大きく進展しているものであり，微小亀裂 においては亀裂表面がほとんど開口していないので目視 検査も容易ではない。したがって，その疑いのある部分 のペンキや污れをきれいに取り除かないと発見すること は難しく，この場合，亀裂表面をすりつぶしてしまい浸 透探傷試験による亀裂検出が困難になった例もある.

そこで, 本研究では, 対傾構のスティフナ隅肉溶接継 手にみられる回し溶接部の止端に沿って発生する表面疲 労亀裂 (Cタイプ) を対象に，各種非破壊試験の適用 性および限界を検討するとともに，特に試験結果に及ぼ す塗膜の影響について調査した。

\section{2. 試験の概要}

工場製作時も含めて，鋼橋によく利用されている非破 壊試験方法をまとめて図一2に示す．鋼橋の現場での検 査で使用できる非破壊試験は, 表面疲労亀裂に対しては, 目視試験 $(\mathrm{VT})$, 浸透探傷試験 $(\mathrm{PT})$, 磁粉探傷試験 (MT), 超音波探傷試験 $(U T)$, 渦流探傷試験 $(E C T)$ であり，放射線透過試験は疲労亀裂が面状であること， また安全面での管理，撮影に必要な作業空間の有無を考 えると現場での検查にはあまり適していない，本研究で は塗膜上からの非破壊試験方法としてこの 5 つの試験方 法を取り上げ，特に目視試験（塗膜切れにより発生した 錆汁の検出）および渦流探傷試験の適用性について検討 した。

供試体は図一3に示す形状のものであり, 塗装後 1 か 月屋外に放置し，その後繰り返し載荷を行った．塗膜は 鋼橋に用いられる一般的な塗装系である．表一1 に塗装 仕様を示すが，プライマー，鉛系さび止め，フタール樹 脂の 5 層塗りである. 塗装膜厚は表一2に示すように, いずれの供試体ともおおよそ $100 \mu \mathrm{m}$ である。繰返し載 荷は $3 \bullet$ 点曲げで行い，隅肉溶接止端部からの種々の大き

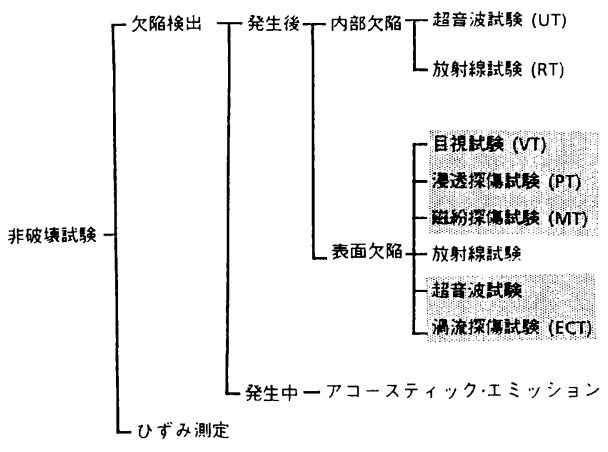

図一2 各種の非破壊試験方法

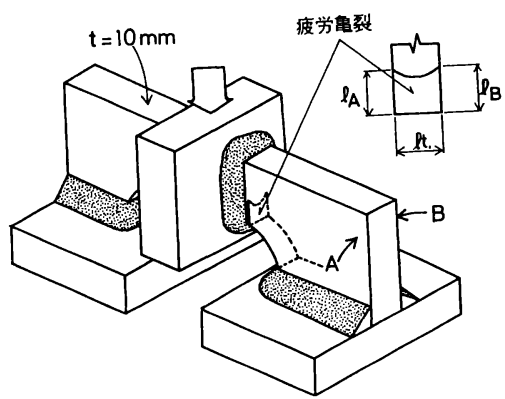

図一3 供試体形状

表一1 塗装仕様

\begin{tabular}{|c|c|c|c|c|}
\hline \multicolumn{2}{|c|}{ 工 程 } & 浍料名 & $\begin{array}{c}\text { 摽輩使用吾 } \\
\left(\mathrm{g} / \mathrm{m}^{2}\right)\end{array}$ & 海裝間隔 $\left(20^{\circ} \mathrm{C}\right)$ \\
\hline \multirow{5}{*}{ 工场望装 } & 第1層 & エッチングブライマー221 & スプレー 130 & \multirow{2}{*}{$12 \mathrm{H}-3 \mathrm{M}$} \\
\hline & \multirow[t]{2}{*}{ 第2雷 } & 鉛系さび止めベイント & \multirow[b]{2}{*}{ スブレー170 } & \\
\hline & & (敘けた用) & & \multirow[t]{2}{*}{ 2D-1M } \\
\hline & \multirow[t]{2}{*}{ 第3扂 } & 鉛系さび止めベイント & \multirow[b]{2}{*}{ スプレー170 } & \\
\hline & & (铁けた用) & & \multirow[t]{2}{*}{$2 \mathrm{D}-6 \mathrm{M}$} \\
\hline \multirow{3}{*}{ 現域泣望 } & \multirow[t]{2}{*}{ 第4居 } & 長油性フタル榯脂涘料 & \multirow[b]{2}{*}{ はけ 110} & \\
\hline & & 中钮(鉄けた用) & & $24 \mathrm{H}-15 \mathrm{D}$ \\
\hline & 第5屈 & 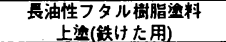 & はけ 105 & \\
\hline
\end{tabular}

表一2 供試体の塗膜厚

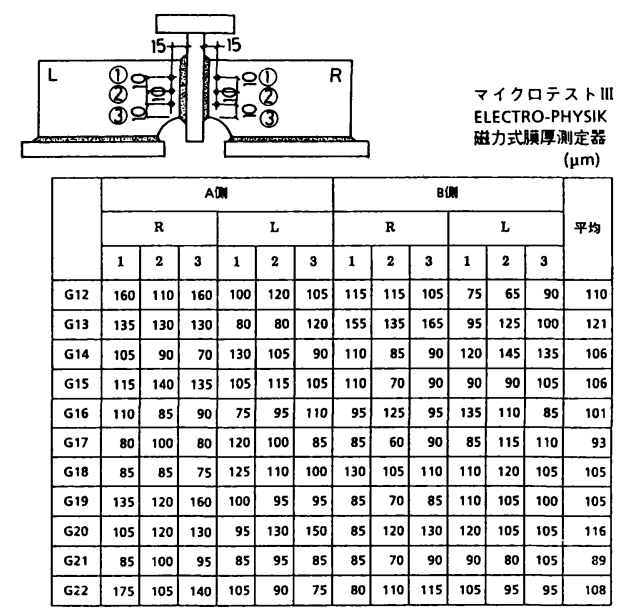

さの亀裂を発生させた.亀裂は,こば面もしくはコ一ナ一 部から発生し，板厚 $10 \mathrm{~mm}$ を貫通して進展する。龟裂 発生部近傍での応力は $100 \sim 140 \mathrm{MPa}$, 繰返し数は 25 〜 $150 \times 10^{4}$ である. 付表一1には亀裂の夕イプおよび寸 法をまとめて示す。亀裂発生後さらに 1 か月屋外に放置 し, 毎日水道水を噴霧して亀裂部より錆汁を発生させた。 このような亀裂発生部に対して,まず塗膜上から VT, $\mathrm{ECT}, \mathrm{MT}, \mathrm{PT}, \mathrm{UT}$ の 5 つ非破壊試験を行い, その 後，塗膜を除去して同様な試験を繰り返した。塗膜除去 は，電動グラインダーを使用すると微小亀裂をつぶして しまう危険性があるために不適当と判断して，塗膜剥離 液を用いて行った。非破壊試験終了後, 亀裂破面を露呈 
して実亀裂寸法と非破壊試験による推定寸法との対応を 検討した。

\section{3. 渦流探傷試験}

\section{（1）試験方法}

渦流探傷試験 ${ }^{8)}$ は携帯型および搬用型の 2 種類の装置 を用いて，それぞれについて試験コイルを種々かえて龟 裂検出能を検討した。表一3に使用装置および試験コイ ルを示す. 試験コイルは市販の $\mathrm{D}, \mathrm{P}, \mathrm{W}$ タイプと F (鉄 芯のコイル径 $14 \mathrm{~mm}$ ) および $\mathrm{S}$ (空芯のコイル径 $9 \mathrm{~mm}$ ) の 5 つのタイプであり, F, S については試験周波数を

\section{表一3 渦流探傷試験装置および条件}

\begin{tabular}{|c|c|c|c|}
\hline \multirow{2}{*}{ 装 置 } & \multicolumn{2}{|c|}{ 試験コイル } & \multirow{2}{*}{ 感度 } \\
\hline & 分 類 & 名 称 & \\
\hline $\begin{array}{l}\text { 携带型 } \\
\text { ブリッシ } \\
\text { アンバラ } \\
\text { ンス方式 }\end{array}$ & 単一方式 & 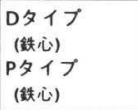 & $\begin{array}{l}\text { ビード止端健全部に } \\
\text { おいてメ酉り } \\
\text { の中央部に設定 }\end{array}$ \\
\hline 搬用型 & $\begin{array}{l}\text { 自己比較方 } \\
\text { 式 }\end{array}$ & 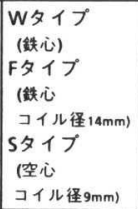 & 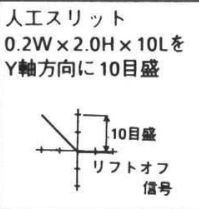 \\
\hline
\end{tabular}

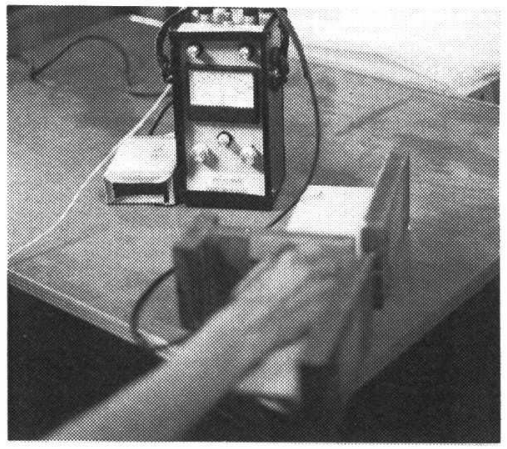

写真一1 渦流探傷試験状況（携帯型）

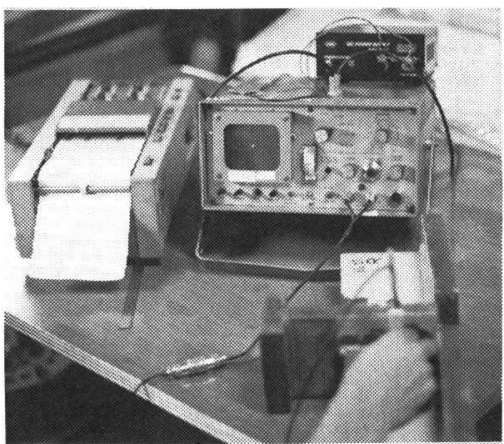

写真一2 渦流探傷試験状況（搬用型）
かえて行った. 図一4 に試験コイルの形状を示す.ここ で，Wタイプのコイル形状は不明のために図示してい ない. W タイプは止端部のジグザグ操作（溶接止端部 に向かって前後走査しながら溶接線に平行に移動する走 査）であり，その他は平行操作（前後走査を伴わず溶接 止端部に沿って平行に移動する操作）である．塗膜上か らの試験では磁粉探傷試験前とし, 塗膜除去後の試験は 磁粉探傷試験による残留磁気の影響を極力小さくするた めに，脱磁処理を行った.

写真一 1 , 写真一 2 には，携帯型および搬用型での探傷 状況を示す．渦流探傷はコイルに交流電流を流すことに よって, 試験体に発生する渦電流が欠陥および材質変化 の影響で変化するのを検出する方法である．携帯型（試 験コイル $\mathrm{D}, \mathrm{P}$ タイプ) では亀裂の有無をへッドホーン の可聴音の有無と音の高低（亀裂発生部の真上では音が 高くなる) から判断した。搬用型（W，F，S タイプ） では, 健全部と亀裂発生部から得られる CRT 上での位 相角の相違から判断した。 写真一3に，W およ゙゙ $\mathrm{F}$ タ プについて健全部と亀裂発生部の CRT 波形の例を示 す. W タイプでは健全部の CRT 波形は $X$ 軸（水平）

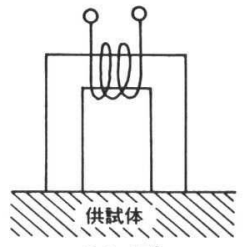

Dタイプ

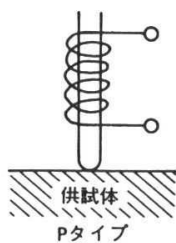

Pタイブ

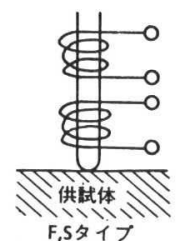

図-4 渦流探傷試験コイル

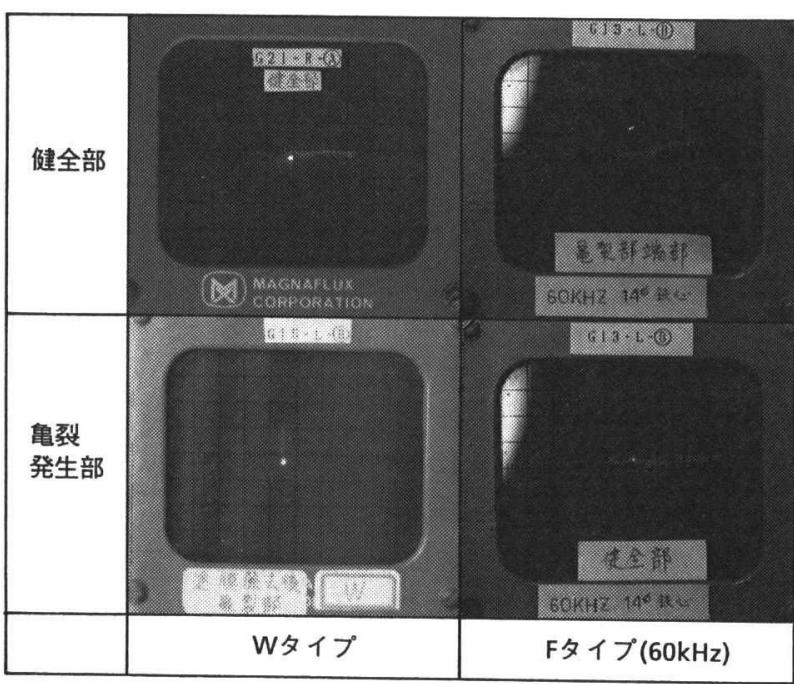

写真一3 渦流探傷試験の代表的な CRT 波形 
上に現われているが, 亀裂発生部の波形は $Y$ 軸（垂直） 上に恋められ，位相角が $90^{\circ}$ ずれていることがわかる. 一方, F タイプではWタイプに比べて渦電流の分布範 井が広いため, 亀裂発生部の波形は隅肉溶接止端部之亀 裂の信号が合成されて現われる。この波形からだけでは 亀裂有無の判別を行うことは難しく, 位相角の相違が出 始める位置之供試体の部材端との相対的な位置関係から 判断した.

\section{(2) 試験結果}

代表的な亀裂破面を写真一 4 に示す。(a)，(b) は板 厚を貫通した亀裂であり, それぞれ側面において 11 $\mathrm{mm}, 4.4 \mathrm{~mm}$ まで進展している. (c)はこば面とコーナー 部に亀裂が発生している例である. 渦流探傷試験におい ては，たとえば（a）の亀裂については，A 面からの探 傷（G-20 LA）では長さ $11 \mathrm{~mm}$ の亀裂，B面からの探 傷 (G-20 LB) では長さ $7.4 \mathrm{~mm}$ の亀裂としている. (c) については直接探傷ができず，ここでは亀裂のないもの として扱った. 表一 4 に渦流探傷試駼結果を示す. 探傷 は塗膜上および塗膜除去後について 7 種類の試験コイル の条件で行い, 亀裂の有無の判定の合否で示してある. 表では探傷面側の亀裂の有無に大別し,さらに亀裂に関 してはコーナ一亀裂, 貫通亀裂に分類して大きい順に並 ベてある。

貫通亀裂についてみてみると, 長さが $10 \mathrm{~mm}$ 以上 (写 真一4の (a)) であると, 塗膜の有無にかかわらず，い ずれのプローブでも検出が可能である.しかし，上り小 さい亀裂を検出する場合には, W タイプ, Fタイプ (周

\section{表-4 渦流探倠試験結果}

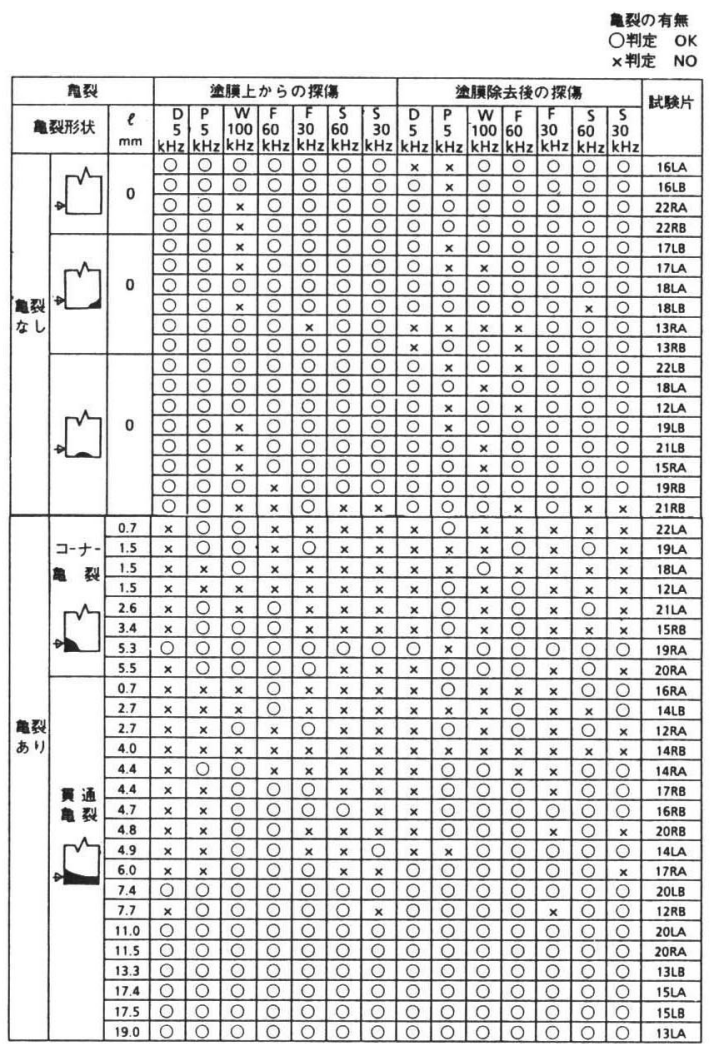

波数 $60 \mathrm{kHz})$ が適しており,やはり塗膜の有無にかか わらず $4.4 \mathrm{~mm}$ (写真一 4 の (a)) の亀裂の検出が可能
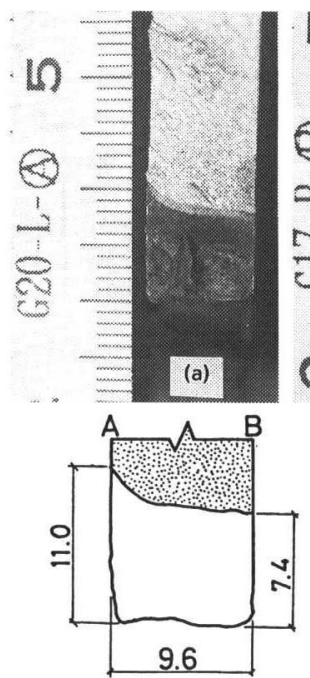

(a)
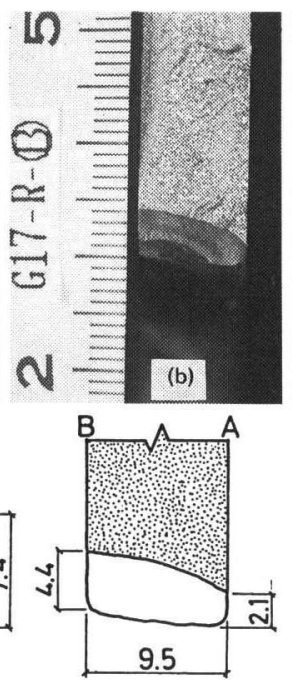

(b)
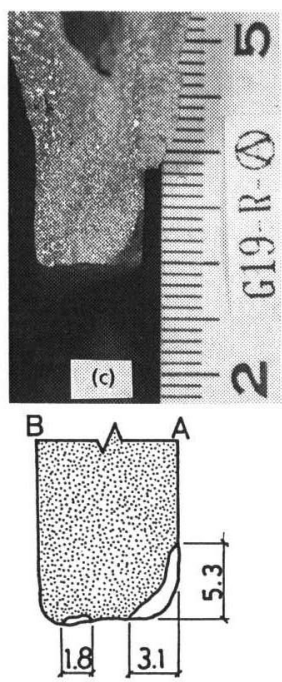

(c)

写真一4 代表的な香裂破面 
表一5 渦流探傷試験による検出率および空振り率

\begin{tabular}{|c|c|c|c|c|c|c|}
\hline \multirow[b]{2}{*}{ 探绩器 } & \multirow[t]{2}{*}{ ブローブ } & \multicolumn{2}{|c|}{ 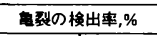 } & \multirow{2}{*}{$\begin{array}{c}\text { 空振り事,\% } \\
\text { (18蔨) }\end{array}$} & \multirow[b]{2}{*}{ 钎録性 } & \multirow[b]{2}{*}{ 作檏性 } \\
\hline & & $\begin{array}{l}10<\ell \\
(5 \text { (個) }\end{array}$ & $\begin{array}{c}4<\ell \\
\text { (14蔨) }\end{array}$ & & & \\
\hline \multirow[b]{2}{*}{ 㩲带型 } & $\begin{array}{c}D \\
(5 \mathrm{kHz})\end{array}$ & $100 \%$ & $50 \%$ & $0 \%$ & \multirow[b]{2}{*}{ なし } & \multirow[b]{2}{*}{ 電源不必要 } \\
\hline & $\begin{array}{c}\mathrm{P} \\
(5 \mathrm{kHz}) \\
\end{array}$ & $100 \%$ & $71 \%$ & $0 \%$ & & \\
\hline \multirow{5}{*}{ 䑳用型 } & $\begin{array}{c}W \\
(100 \mathrm{kHz})\end{array}$ & $100 \%$ & $100 \%$ & $50 \%$ & \multirow{5}{*}{ あり } & \multirow{5}{*}{ 電源必要 } \\
\hline & $\begin{array}{c}F \\
(60 \mathrm{kHz})\end{array}$ & $100 \%$ & $93 \%$ & $11 \%$ & & \\
\hline & $\begin{array}{c}F \\
\text { (30kHz) }\end{array}$ & $100 \%$ & $71 \%$ & $6 \%$ & & \\
\hline & $\begin{array}{c}5 \\
(60 \mathrm{kHz})\end{array}$ & $100 \%$ & $64 \%$ & $6 \%$ & & \\
\hline & $\begin{array}{c}\mathrm{S} \\
(30 \mathrm{kHz})\end{array}$ & $100 \%$ & $57 \%$ & $6 \%$ & & \\
\hline
\end{tabular}

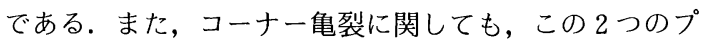
ローブでは $5 \mathrm{~mm}$ 以上の亀裂の検出が可能である.

一方, 亀裂のない場合についてみると, W タイプで は亀裂ありと判定（空振り）するものが多い.W夕イ プは他のプローブと比較して渦電流の分布範囲が狭く, 集中していることから端面（こば面）効果の影響が小さ く, 微小亀裂の検出が可能である.しかしながら，材質 の不均一, 残留応力, コイルと試験面とのなす角度など, 位相角への影響が他のタイプに比べて大きく空振り率も 多くなっている.今回の実験においては亀裂と判定した 位相角を $10^{\circ}$ 程度 (塗膜除去後は $20^{\circ}$ 程度) としたが, 設定角度をもう少し大きくするならば空振り率は減少す る.ただし，この場合には，検出限界寸法が大きくなる．

また, F夕イプは合致率, 空振り率とも他のコイルと 比較するとバランスがとれており，良好な結果となって いる. しかしながら，F夕イプはリフトオフ信号がW夕 イプに比べて大きく，また，溶接止端部に沿った平行走 査により，コイルと隅肉溶接端部（こば面）の相対位置 から亀裂の有無を判定することから，探傷者の技量に左 右され, 再現性の点では十分とはいえない欠点もある.

今回モデル化したような回し溶接端部から発生する亀 裂の渦流探傷試験においては, 端部からの疑似信号によ り亀裂信号がマスクされること，あるいは他の要因によ る疑似信号の発生などから, 亀裂長さの推定値亡実亀裂 長さの間にはかなりばらつきが大きく，正確な寸法推定 は不可能であった（付表一2に推定亀裂寸法を示す）.

このようにみてくると渦流探傷は塗膜上からの亀裂の有 無を判定する粗探傷として有効な方法と考えられる.

表一5に塗膜上からの探傷について亀裂検出限界寸法 を $10 \mathrm{~mm}, 4 \mathrm{~mm}$ とした場合の各プローブでの亀裂検出 率および空振り率を示す。亀裂の検出限界寸法を小さく して, さらに検出率を高めると, 空振り率が高くなる傾 向にある，したがって，渦流探傷は適用する条件によっ て適切なプローブを選択する必要がある，たとえば，亀 裂検出限界寸法を $10 \mathrm{~mm}$ とすると, 作業性の点からも $\mathrm{D}, \mathrm{P}$ タイプがよく, さらに検出限界寸法を小さくする
場合には, 空振り率が高くなるもののFタイプ (周波数 $60 \mathrm{kHz}$ ), W タイプの使用が適している. この場合, 探 傷記録を残すことも可能である.

\section{4. 目視，磁粉，浸透探傷試験}

\section{（1）試験方法}

渦流探傷試験と同様に，目視，磁粉，浸透探傷試験に ついて, 塗膜上, 塗膜除去後の亀裂検出性能の検討を行っ た. 目視検查はルーペを用いて亀裂の有無を観察し, 特 に, 塗膜上からの試験では主として塗膜切れ, 錆汁の発 生をチェックした。磁粉探傷試験, 浸透探傷試験は亀裂 の検出性能, 現場での作業性を考慮して蛍光湿式交流極 間法, 溶剤除去性染色浸透法とした。表一6, 表一7に はそれぞれの探傷条件を示す。

\section{表一6 磁粉探傷試験の装置および条件}

\begin{tabular}{|c|c|}
\hline \multirow{2}{*}{$\begin{array}{l}\text { ハンディマクナ } \\
\text { ブラックライト }\end{array}$} & \multirow{3}{*}{ 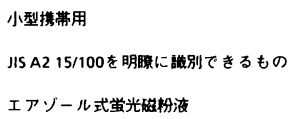 } \\
\hline & \\
\hline 恝 & \\
\hline 磞化奄流の種類 & 交流 \\
\hline 磁化方法 & 極 間 法 \\
\hline 磁柾間の础埸の強さ & 30 Өe以上 \\
\hline 磁䎦適用に対する & 連 統 法 \\
\hline 磁化の時間 & \\
\hline 通電時間 & 5-7秒 \\
\hline 磁粉の粒度 & $3 \mu$ 以下 \\
\hline 磁轵の分散媒 & エァソーールタイブの油ベース \\
\hline 娭查液淈度 & $1.5 \mathrm{~g} / \ell$ \\
\hline 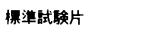 & JIS A2 15/100 R形 \\
\hline 考 & $\begin{array}{l}\text { 磁梗の接触状態が十分である事を確かめ } \\
\text { て通電する。また、楁接止端部に㛟查液 } \\
\text { が西接かからないように散布する }\end{array}$ \\
\hline
\end{tabular}

表一7浸透探傷試験の装置および条件

\begin{tabular}{|c|c|}
\hline $\begin{array}{l}\text { 漫透剂 } \\
\text { 洗浄剂 } \\
\text { 現像剂 }\end{array}$ & 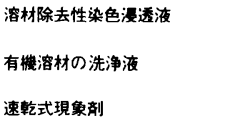 \\
\hline 方 法 & 染色溶绪除去性 \\
\hline 検査面温度 & $10 \sim 18^{\circ} \mathrm{C}$ \\
\hline 漫透時間 & $30 \sim 40$ 分 \\
\hline 現像時間 & $5 \sim 60$ 分 \\
\hline 潇考 & 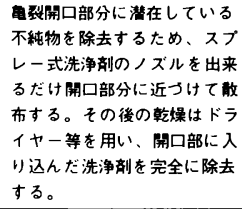 \\
\hline
\end{tabular}




\section{(2) 試験 結果}

表一8に試験結果をまとめて示す. 目視検査, 磁粉探 傷試験, 浸透探傷試験について塗膜上, 塗膜除去後の試 験における亀裂検出の有無を表わしたものである(それ ぞれの推定寸法については付表一3に示す). 表では亀 裂をこば面の亀裂, コーナー亀裂, 貫通亀裂に分類し, 寸法の大きい順に並べてある.なお，表中に渦流探傷試 験, 超音波探傷試験結果を併記したが, 渦流探傷試験に 関しては，表一4のFタイプ $(60 \mathrm{kHz})$ のプローブの結 果であり, 超音波探傷試験については次章で詳細に述べ ることにする.

こば面の亀裂については, 塗膜の有無にかかわらず, いずれの試験方法でも検出は困難である，写真一 5 に最 も大きい亀裂の破面 ( G-13R) を示すが、こば面の亀 裂は表面長さ, 深さとも小さく, また, 作業的にもスカ ラップ部の狭あいな部分に位置するために検出しづら い.なお, 超音波探傷試験, 渦流探傷試験は探傷が作業 上困難なため, 対象外としている.

\section{（3）塗膜上からの白裂検出}

コーナー亀裂と貫通亀裂についての塗膜上からの試験 についてみてみる.いずれの亀裂も長さが $3.4 \mathrm{~mm}$ で塗 膜切れを起こし, その後の暴露により錆汁が発生して目 視検査が可能となっている. 長さ $3.4 \mathrm{~mm}$ のコーナー亀 裂（G-15 RB）の破面および塗膜上からの試験結果を 写真一 6 に示す. 回し溶接部の止端部に沿って錆汁の発 生が認められ目視検査での亀裂の確認が可能である。ま た, 磁粉探傷試験, 浸透探傷試験でも同様に亀裂指示模

\section{表-8 探傷結果}

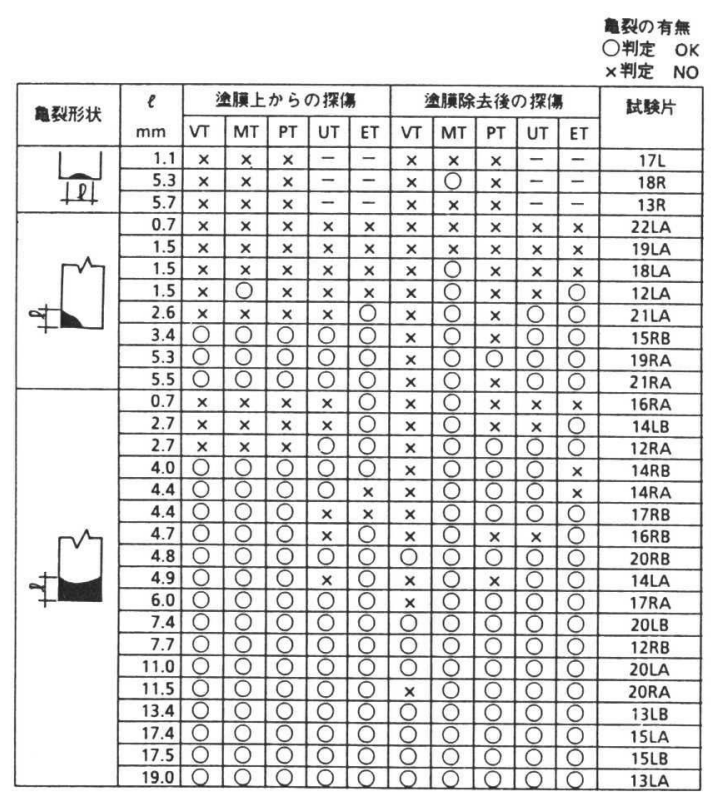

様が現われている，ところで，今回，亀裂が発生してい ない 4 か所の回し溶接部のうち, 1 か所 (G-22 RA) において塗膜切れが認められた，写真一7に探傷結果を 示すが, この場合磁粉探傷試験, 浸透探傷試験でも亀裂 指示模様が現われている. 塗膜上からの検査では, 磁粉 探傷試験, 浸透探傷試験の結果は塗膜切れによって左右 され, 試験方法自体の信頼性は低い。

図一5に目視検査による推定亀裂寸法と実寸法の対応 を示す。目視検査による寸法推定はかなりばらつきが大 きくなっている．したがって，塗膜上からの目視検査の みで亀裂寸法を推定するのは困難であり, 現場での龟裂

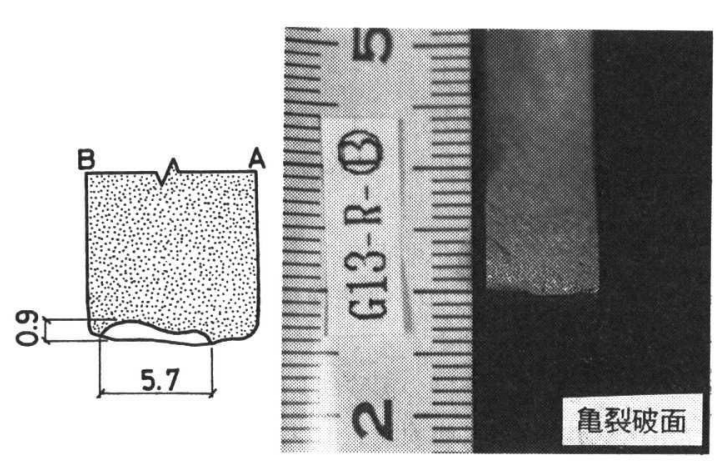

写真一5 こば面に発生した癿裂（G-13 R）
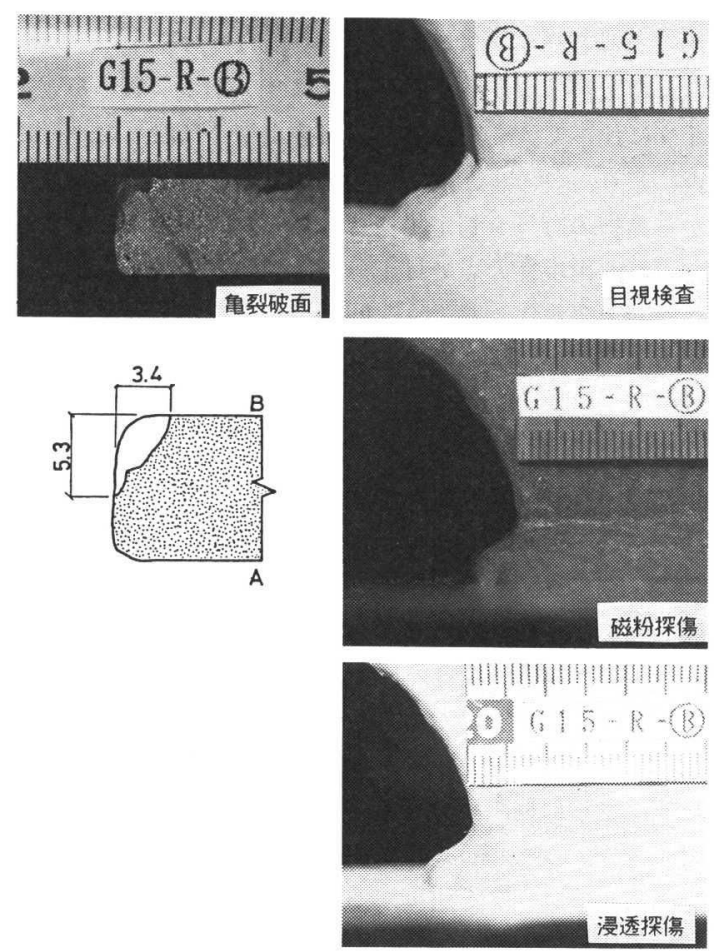

写真一 6 代表的な奄裂の探傷試験結果 (G-15 RB) 


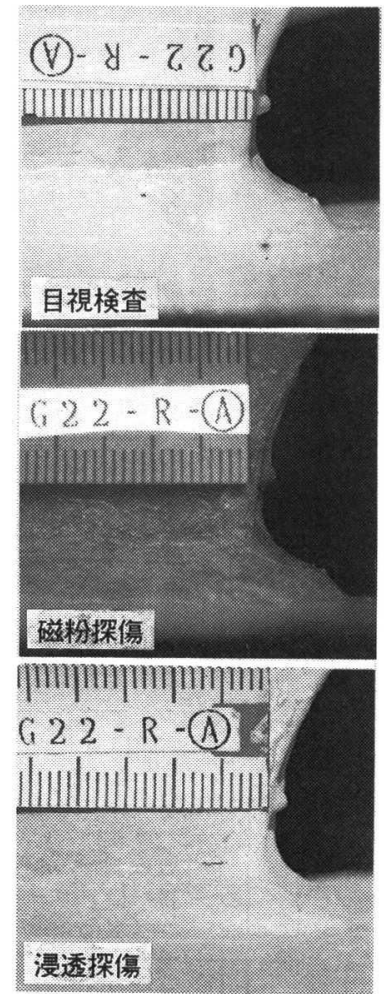

写真一7 代表的な香裂の探傷試験結果 (G-22 RA)

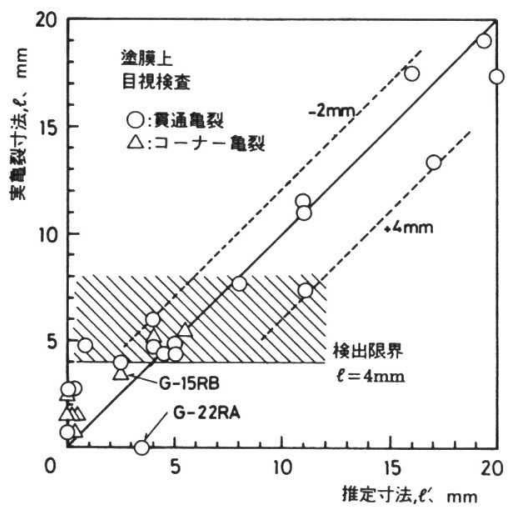

図一5 目視検査による推定寸法と寒寸法の関係（塗膜上）

の有無を確認する粗検査として有効であるといえる。こ の場合, 検出限界はおおよそ $4 \mathrm{~mm}$ と判断できる.ただ し亀裂発生を伴わない塗膜切れもあり，現場での作業で は先の渦流探傷式験を併用するのが良好と考えられる.

\section{（4）䤰膜除去後の亀裂検出}

塗膜除去後の検查においては, 目視検査, 浸透探傷試 験とも塗膜上に比べて検出限界寸法が大きくなってい る.目視検査では塗膜上からは主に錆汁の発生で判断し，
塗膜切れ部を検出したが, 塗膜を除去した場合, 疲労亀 裂はきわめてシャープであり，ほとんど開口していない ためにその識別が困難になるものと考えられる．また， 浸透探傷試験に関しても亀裂面への浸透液の浸み込みが 十分でないことから亀裂と健全部とのコントラストが低 く, 小さな亀裂の検出が困難になるものと推定できる.

しかしながら, 磁粉探傷試験は目視検査, 浸透探傷試 験に比べて検出精度が向上し, 貫通亀裂で $0.7 \mathrm{~mm}$, コー ナ一亀裂でも $1.5 \mathrm{~mm}$ の微小亀裂の検出が可能である. 図一6, 図一7 に磁粉探傷試験, 浸透探傷試験について, 塗膜除去後の推定寸法亡実亀裂寸法の関係を示す. 磁粉 探傷試験は $2 \mathrm{~mm}$ 未満のコーナー亀裂の一部は検出でき ず，検出限界は安全側からみて $2 \mathrm{~mm}$ と判断することが できる．また，寸法推定精度はほとんゼが土1 $\mathrm{mm}$ の範 囲内に収まっている。浸透探傷試験は $6 \mathrm{~mm}$ 末満の亀裂 については検出できない場合があり, 検出限界はおおよ そ $6 \mathrm{~mm}$ となる. 寸法推定についても全体に過小評価之

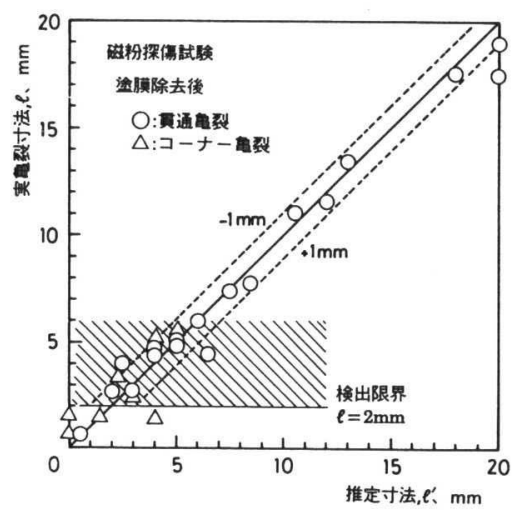

図一6磁粉探傷試験による推定寸法と実寸法の関係 (㓌膜除去後)

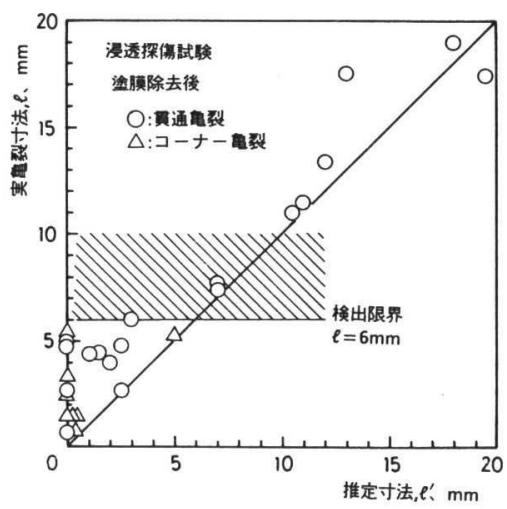

図一7浸透探傷試験による推定寸法と実寸法の関係 （塗膜除去後） 

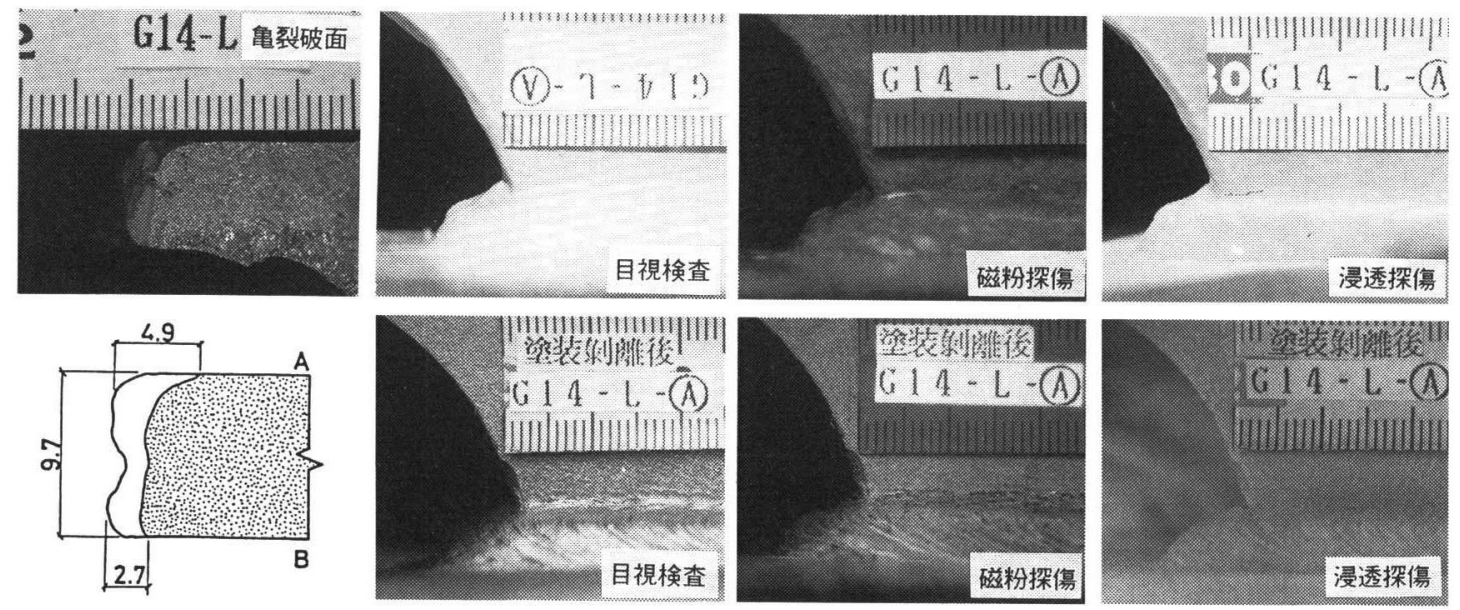

写真一 8 塗膜上および金膜除去後の探傷試験結果 (G-14 LA)

なっている.この傾向は, 亀裂のタイプが異なるものの, 先に行った図一1の A, B タイプの亀裂に関する実験と 同じである.

写真一8に代表的な試験結果を示す. 長さ $4.9 \mathrm{~mm} の$ 貫通亀裂 (G-14 LA) に関して, 塗膜上, 塗膜除去後 の目視検査, 磁粉探傷試験, 浸透探傷試験を比較して並 ベてある. 塗膜上からの目視検査, 磁粉探傷試験, 浸透 探傷試験ではいずれも亀裂を検出しているが, 塗膜除去 後においては，磁粉探傷試験は明確に指示模様が現われ ているものの, 目視検査, 浸透探傷試験では亀裂が検出 できていない.

\section{5. 超音波探傷試験}

超音波探傷試験に関しては, 亀裂の検出および寸法推 定, さらに, 亀裂形状の確認の可能性を検討した。図一 8 に探傷の概要を, 表一 9 には使用機器および探傷条件 を示す.試験に際してあらかじめ塗膜の影響を調査した が, 今回の供試体の $100 \mu \mathrm{m}$ 程度の塗膜は探傷感度にほ とんど影響を及ぼさず，低下量は 0 — $2 \mathrm{~dB}$ であった。 したがって，探傷にあたっては塗膜上，塗膜除去後とも 同じ感度としている，龟裂の検出は，亀裂と板表面にで きるコーナーからのエコーを捕える方法であり，この コーナーエコーが消失する位置を亀裂端部と判断して寸 法を求めた.

図一 9 に，塗膜上，塗膜除去後のそれぞれについて， 推定亀裂寸法と実亀裂寸法の関係を示す.プロットはか なりばらついているが, 塗膜上, 塗膜除去後の差はほ上 んよ゙みられない，貫通亀裂の検出限界寸法は $5 \mathrm{~mm}$ であ り,コーナー亀裂でも長さが $5 \mathrm{~mm}$ であれば十分に検出 可能である. 今回使用した探触子はミニチュアタイプで あるが，その幅が $10 \mathrm{~mm}$ となっている.したがって，

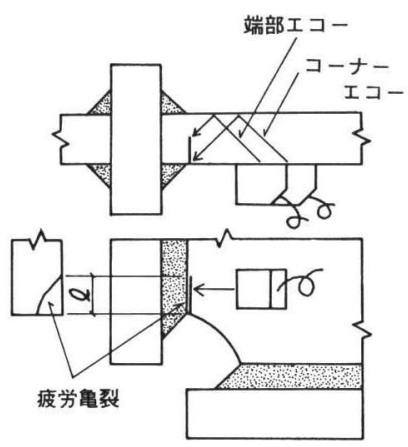

図一8 超音波探傷試験方法

\begin{tabular}{|c|c|}
\hline 探躶器 & ハルス反期式 \\
\hline 探触子 & $\begin{array}{l}\text { 高分蛊能型ノーマルミニチュフ } \\
\left(5 \mathrm{MHz}, 45^{\circ}\right)\end{array}$ \\
\hline 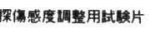 & スリット武腊片 $(0.2 \mathrm{~W} \times 1.0 \mathrm{H} \times 10 \ell)$ \\
\hline コーナーエコーの & 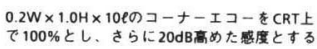 \\
\hline 端部エコーの模出 & 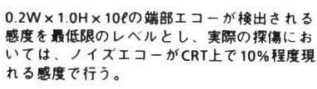 \\
\hline 周波教 & $5 \mathrm{MHz}$ \\
\hline 届折笛(公称) & $45^{\circ}$ \\
\hline 接腈背算 & グリセリン $75 \%$ 以上 \\
\hline
\end{tabular}

亀裂寸法が $5 \mathrm{~mm}$ 末満であると探触子は探傷面から外れ てしまう.この場合, 探触子を傾けて探傷することにな るが, ビームが亀裂面に直角にあたらず, 亀裂検出精度 が悪くなるものと考えられる.

一方, 推定寸法はいずれもかなり過大評価となってお 


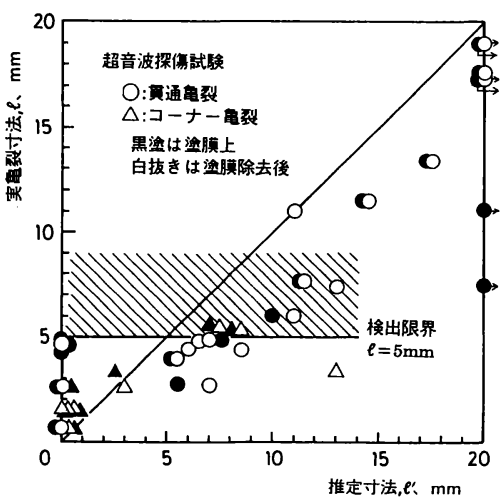

図一9 超音波探傷試験による推定寸法と実寸法の関係

り，正確な寸法推定は困難であるといえる，亀裂は止端 部に沿って発生しており, 供試体端部の影響, およびア ンダーカットと亀裂との判別が難しいことから, 過大評 価になったものと考えられる.

なお，コーナー亀裂に対して，端部エコ一法による亀 裂形状の推定を試みた。今回板厚が薄いこと, 亀裂が比 較的小さく端部に位置することにより，明確な端部エ コーは捕えられなかった. したがって，回し溶接部の材 端の止端から発生する亀裂に対しては，超音波探傷試験 はコーナーエコーによる亀裂の検出しかできず，この場 合, 磁粉探傷試験に比べて検出限界寸法, 寸法推定精度 はかなり悪くなっている.

\section{6. まと め}

塗装が施された鋼橋部材を対象にして，回し溶接端部 から発生する疲労亀裂について各種非破壊試験の適用性 について検討した，表一10に，亀裂検出限界寸法およ び寸法推定精度をまとめて示すが，結論を要約すると以 下のとおりである.

（1）塗膜上からの亀裂検出に対しては，塗膜切れに より錆汁が発生している場合は, 目視検査でも $4 \mathrm{~mm}$ 以 上の亀裂の検出が可能であり, 磁粉探傷試験, 浸透探傷 試験での検出はこの塗膜切れに左右されるものと考えら れる.さらに，渦流探傷試験においては，適切なプロー ブと探傷条件を選ぶならば $5 \mathrm{~mm}$ 以上の亀裂の検出が可 能である.

（2）目視検査, 渦流探傷試験は正確な寸法推定が不 可能であり, 塗膜上からの粗探傷として適用し，何らか の亀裂指示が認められた場合には塗膜を除去して精密検 査を行うのがよい.

（3）精密検査としては磁粉探傷試験が優れており, $2 \mathrm{~mm}$ 以上の亀裂に対して $1 \mathrm{~mm}$ の精度で検出が可能 である。浸透探傷試験, 超音波探傷試験による亀裂寸法
表一10 各種非破懐試験の亀裂検出限界寸法および精度

\begin{tabular}{|c|c|c|c|}
\hline & \multicolumn{2}{|c|}{ 渑裂検出限界寸法，mm } & \multirow{2}{*}{ 寸法推定精度 } \\
\hline & 塗膜上 & 崄膜除去後 & \\
\hline 目視検査 & 4.0 & 8.0 & ばらつき大 \\
\hline 磁粉探倹試臨 & $(4.0)$ & 2.0 & 適正 $( \pm 1 \mathrm{~mm})$ \\
\hline 漫透探傷試験 & $(4.0)$ & 8.0 & 過小評価 \\
\hline 超音波探僵試験 & 5.0 & 5.0 & 過大評価 \\
\hline 渦流探倠試唪 & 5.0 & 5.0 & 不 \\
\hline
\end{tabular}

推定は磁粉探傷試験に比べると信頼性が低い.

なおここで述べた非破壊試験の結果は亀裂の開口量 に左右され，どのような応力状態によって進展したかに よって異なってくる. さらに，探傷者，探傷装置によっ ても影響を受ける．また，塗膜に関しても，1 か月後の ものと数年経過した塗膜とでは影響度合も異なる．さら に，室内と屋外の現場との作業環境の違いによってもそ の度合が異なる。したがって，今後とも，種々の条件の もとで実験を進めるとともに，現場での実作業を行うな かで広くデータを収集して検討していく必要がある.

付表一1 供試体の亀裂寸法

\begin{tabular}{|c|c|c|c|c|c|}
\hline \multicolumn{2}{|c|}{ 試験片 } & \multirow{3}{*}{$\frac{\text { 愚裂形状 }}{\bigcirc}$} & \multicolumn{3}{|c|}{ 亀裂寸法，mm } \\
\hline & & & \multirow{2}{*}{$\frac{e_{A}}{2.7}$} & \multirow{2}{*}{$\begin{array}{l}\mathrm{et} \\
9.5\end{array}$} & \multirow{2}{*}{$\frac{\ell_{B}}{7.7}$} \\
\hline$G-12$ & $\mathrm{R}$ & & & & \\
\hline$G-12$ & L & $\triangle$ & 1.5 & 2.8 & - \\
\hline \multirow{2}{*}{$G-13$} & $R$ & $\square$ & - & 5.7 & - \\
\hline & $\mathrm{L}$ & 0 & 19.0 & 8.7 & 13.4 \\
\hline \multirow{2}{*}{$G-14$} & $R$ & 0 & 4.4 & 6.1 & 4.0 \\
\hline & L & $\mathrm{O}$ & 4.9 & 9.7 & 2.7 \\
\hline \multirow[t]{2}{*}{$G-15$} & $R$ & $\triangle$ & - & 5.3 & 3.4 \\
\hline & $L$ & $\mathrm{O}$ & 17.4 & 9.3 & 17.5 \\
\hline \multirow[t]{2}{*}{$G-16$} & $\mathrm{R}$ & 0 & 0.7 & 8.9 & 4.7 \\
\hline & $\mathrm{L}$ & なし & - & - & - \\
\hline \multirow[t]{2}{*}{$G-17$} & $\mathrm{R}$ & 0 & 6.0 & 9.5 & 4.4 \\
\hline & $L$ & $\square$ & - & 1.1 & - \\
\hline \multirow[t]{2}{*}{$G-18$} & $R$ & $\square$ & - & 5.3 & - \\
\hline & $\mathrm{L}$ & $\triangle$ & 1.5 & 0.8 & - \\
\hline \multirow[t]{2}{*}{$G-19$} & $R$ & $\triangle \square$ & 5.3 & $3.1+1.9$ & - \\
\hline & $L$ & $\triangle$ & 1.5 & 0.9 & - \\
\hline \multirow[t]{2}{*}{$G-20$} & $R$ & $\mathrm{O}$ & 11.5 & 9.6 & 4.8 \\
\hline & $\mathrm{L}$ & 0 & 11.0 & 9.6 & 7.5 \\
\hline \multirow[t]{2}{*}{$G-21$} & $R$ & $\triangle$ & 5.5 & 1.6 & - \\
\hline & L & $\triangle$ & 2.6 & 2.4 & - \\
\hline \multirow[t]{2}{*}{$G-22$} & $R$ & なし & - & - & - \\
\hline & $\mathrm{L}$ & $\triangle$ & 0.7 & 8.6 & - \\
\hline
\end{tabular}


付表一3 各種非破壊試験による推定重裂寸法

秋長さ，, $\mathrm{mm}$

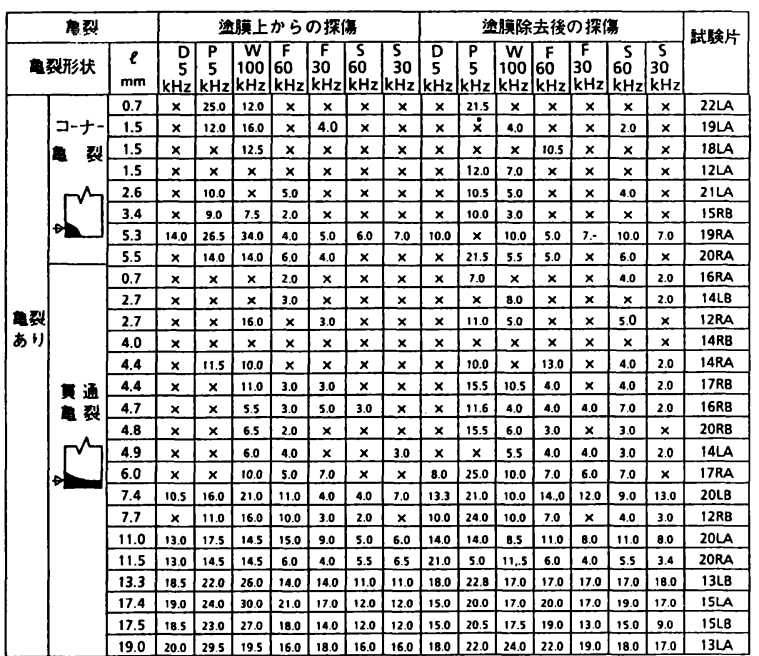

\section{参 考 文 献}

1) 明石：溶接部疲労の現状と研究, 土木学会論文報告集, 第 350 号, 1884.10.

2）三木：構造物と安全性一疲労と安全, 土木技術, Vol. 38, No. 4, 1983. 4.

3）西川：道路橋における疲労問題と補修・補強, 橋梁と基 礎, Vol.17, No. 8, 1983.8.

4) 阿部・谷口・阿部：鋼鉄道橋における疲労問題と補修・ 補強, 橋梁と基礎, Vol.17, No.8, 1983.8.

5）谷口・阿部・阿部：鉄道橋の疲労変状一垂直補剛材下端, 構造工学論文集, Vol. 33 A, 1987. 3 .

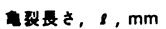

\begin{tabular}{|c|c|c|c|c|c|c|c|c|c|c|}
\hline \multirow{2}{*}{ 䤃形状 } & \multirow[t]{2}{*}{$\ell$} & \multicolumn{4}{|c|}{ 逢䐜上からの探僬 } & \multicolumn{4}{|c|}{ 㳗膜除去後の探罚 } & \multirow[t]{2}{*}{ 試非片 } \\
\hline & & VT & MT & PT & UT & VT & MT & PT & UT & \\
\hline & 1.1 & $x$ & $x$ & $x$ & - & $x$ & $x$ & $x$ & - & $17 \mathrm{~L}$ \\
\hline & 5.3 & $x$ & $x$ & $x$ & $=$ & $x$ & 7.5 & $x$ & - & $18 R$ \\
\hline & 5.7 & $x$ & $x$ & $x$ & - & $x$ & $x$ & $x$ & - & $13 R$ \\
\hline \multirow{8}{*}{ 車D } & 0.7 & $x$ & $x$ & $x$ & $x$ & $x$ & $x$ & $x$ & $x$ & $22 L A$ \\
\hline & 1.5 & $x$ & $x$ & $x$ & $x$ & $x$ & $x$ & $x$ & $x$ & 19LA \\
\hline & 1.5 & $x$ & $x$ & $x$ & $x$ & $x$ & 1.5 & $x$ & $x$ & $18 L \mathrm{~A}$ \\
\hline & 1.5 & $x$ & 2.5 & $x$ & $x$ & $x$ & 4.0 & $x$ & $x$ & $12 L A$ \\
\hline & 2.6 & $x$ & $x$ & $x$ & $x$ & $x$ & 3.0 & $x$ & 3.0 & $21 L A$ \\
\hline & 3.4 & 2.5 & 2.5 & 2.5 & 2.5 & $x$ & 2.2 & $x$ & 13.0 & 15RB \\
\hline & 5.3 & 4.0 & 6.0 & 4.0 & 8.0 & $x$ & 4.0 & 5.0 & 8.5 & 19RA \\
\hline & 5.5 & 5.5 & 5.0 & 5.5 & 7.0 & $x$ & 5.0 & $x$ & 7.5 & $21 R A$ \\
\hline \multirow{18}{*}{ of } & 0.7 & $x$ & $x$ & $x$ & $x$ & $x$ & 0.5 & $x$ & $x$ & 16RA \\
\hline & 2.7 & $x$ & $x$ & $x$ & $x$ & $x$ & 2.0 & $x$ & $x$ & 14LB \\
\hline & 2.7 & $x$ & $x$ & $x$ & 5.5 & $x$ & 3.0 & 2.5 & 7.0 & 12RA \\
\hline & 4.0 & 2.5 & 3.0 & 2.5 & 5.5 & 2.5 & 2.5 & 2.0 & 5.5 & $14 \mathrm{RB}$ \\
\hline & 4.4 & 5.0 & 5.0 & 5.0 & 8.5 & $x$ & 6.5 & 1.0 & 8.5 & 14RA \\
\hline & 4.4 & 4.5 & 9.5 & 4.6 & $x$ & $x$ & 4.0 & 1.5 & 6.0 & 17RB \\
\hline & 4.7 & 4.0 & 5.0 & 4.0 & $x$ & $x$ & 4.0 & $x$ & $x$ & 16RB \\
\hline & 4.8 & 0.8 & 6.0 & 1.0 & 7.5 & 2.5 & 5.0 & 2.5 & 6.5 & 20RB \\
\hline & 4.9 & 5.0 & 5.0 & 5.0 & $x$ & $x$ & 5.0 & $x$ & 5.0 & $14 \angle \mathrm{A}$ \\
\hline & 6.0 & 4.0 & 7.0 & 7.0 & 10.0 & $x$ & 6.0 & 3.0 & 11.0 & 17RA \\
\hline & 7.4 & 111.0 & 10.0 & 11.5 & 26.7 & 5.5 & 7.5 & 7.0 & 13.0 & $20 R A$ \\
\hline & 7.7 & 8.0 & 8.0 & 8.0 & 11.5 & 8.0 & 8.5 & 7.0 & 11.5 & $20 \mathrm{LB}$ \\
\hline & 11.0 & 11.0 & 11.0 & 11.5 & 26.0 & 7.0 & 10.5 & 10.5 & 11.0 & 12RB \\
\hline & 11.5 & 11.0 & 9.0 & 11.0 & 14.5 & $x$ & 12.0 & 11.0 & 14.5 & $20 L A$ \\
\hline & 13.4 & 17.0 & 15.0 & 17.0 & 17.5 & 11.0 & 13.0 & 12.0 & 17.5 & $13 \angle \mathrm{B}$ \\
\hline & 17.4 & 20.0 & 20.0 & 20.0 & 22.5 & 17.0 & 20.0 & 19.5 & 22.0 & $15 \angle A$ \\
\hline & 17.5 & 16.0 & 17.0 & 17.0 & 20.0 & 12.0 & 18.0 & 13.0 & 20.0 & $15 \angle B$ \\
\hline & 19.0 & 19.5 & 20.0 & 20.0 & 22.5 & 17.0 & 20.0 & 18.0 & 20.5 & $13 \mathrm{LA}$ \\
\hline
\end{tabular}

6）坂本・阿部・深沢：TIG 処理による疲労亀裂補修の施工 試験, 土木学会第 42 回年次学術講演会講演概要集, 1987. 9 .

7）三木・深沢・加藤・大畦：表面疲労亀裂検出に対する各 種非破壊試験の適用性, 土木学会論文報告集, 第 386 号, 1987.10.

8）日本非破壊検查協会：非破壊試験概論，1984.

(1987.10.28 - 受付) 